Columbia Law School

Scholarship Archive

2014

\title{
Asking the Right Questions in Copyright Cases: Lessons from Aereo and its International Brethren
}

\author{
Rebecca Giblin \\ giblinchen@gmail.com \\ Jane C. Ginsburg \\ Columbia Law School, jane.ginsburg@law.columbia.edu
}

Follow this and additional works at: https://scholarship.law.columbia.edu/faculty_scholarship

Part of the Intellectual Property Law Commons, and the International Law Commons

\section{Recommended Citation}

Rebecca Giblin \& Jane C. Ginsburg, Asking the Right Questions in Copyright Cases: Lessons from Aereo and its International Brethren, COLUMBIA LAW \& ECONOMICS WORKING PAPER No. 504 (2014).

Available at: https://scholarship.law.columbia.edu/faculty_scholarship/1896

This Working Paper is brought to you for free and open access by the Faculty Publications at Scholarship Archive. It has been accepted for inclusion in Faculty Scholarship by an authorized administrator of Scholarship Archive. For more information, please contact scholarshiparchive@law.columbia.edu. 


\title{
The Center for Law and Economic Studies \\ Columbia University School of Law \\ 435 West $116^{\text {th }}$ Street \\ New York, NY 10027-7201
}

(212) 854-3739

\section{Asking the right questions in copyright cases: \\ Lessons from Aereo and its international brethren}

\author{
Rebecca Giblin, Monash University \\ Jane C. Ginsburg, Columbia University School of Law
}

Working Paper No. 504

December 16, 2014

An index to the working papers in the Columbia Law School Working Paper Series is located at

http://web.law.columbia.edu/law-economic-studies/working-papers 


\title{
Asking the right questions in copyright cases:
}

\author{
Lessons from Aereo and its international brethren * \\ Rebecca Giblin $^{* * *}$ and Jane C. Ginsburg ${ }^{* * * *}$
}

\begin{abstract}
Aereo was a US-based service that made unique copies of broadcast programs from individual antennae for each requesting user, for individual retransmission near-live or at some point in the future. To the uninitiated, it makes no sense for a company to design a television transmission service that utilises thousands of tiny antennae and thousands of copies to deliver signals to users. Wouldn't it be much more efficient to use just one of each? And surely, when it comes to copyright liability, wouldn't more copies result in more infringement, not less? However, Aereo's strategy made a lot of sense when viewed through the prism of US copyright law as then interpreted. In this paper we argue that US judicial decisions focusing on the "wrong" questions in assessing liability for copyright infringement directly encouraged Aereo's business model. We then discuss the Supreme Court's recent ruling that Aereo's transmission of signals "near-live" does fall within the scope of the exclusive right of public performance, and argue that, in correcting the Second Circuit's erroneous inquiries, the Supreme Court raised some "wrong" questions of its own. We also examine the legal responses to Aereo's predecessors in Singapore, Japan, Australia, Germany, France and the EU to determine whether similarly "wrong" questions have
\end{abstract}

* Some parts of this paper have been developed or drawn from the authors' previous work on this topic. See Rebecca Giblin \& Jane C. Ginsburg, We Need to Talk About Aereo: Copyright-Avoiding Business Models, Cloud Storage and a Principled Reading of the "Transmit" Clause, Colum. L. \& Economics Working Paper No. 480 (2014); Rebecca Giblin \& Jane C. Ginsburg, We (Still) Need to Talk About Aereo: New Controversies and Unresolved Questions After the Supreme Court's Decision (forthcoming, 38 Columbia Journal of Law \& the Arts (2015)); Jane C. Ginsburg, Letter from the US: Exclusive Rights, Exceptions, and Uncertain Compliance with International Norms (forthcoming, Revue Internationale du Droit d'Auteur (July 2014)); Rebecca Giblin, Stranded in the Technological Dark Ages: Implications of the Full Federal Court's Decision in NRL v Optus 35 European Intellectual Property Review 632 (2012). Many thanks for research assistance to Taylor Jones, Columbia Law School class of 2014, and to Nell Ethridge, Columbia Law School class of 2015.

** Senior Lecturer, Monash University (Melbourne, Australia). Thanks to Monash University's Research Accelerator Grant, which partly supported the development of this work over 2013-2014.

${ }^{* * *}$ Morton L. Janklow Professor of Literary and Artistic Property Law, Columbia University School of Law. This article benefited from the support of the Philippe P. Dauman Faculty Research Fund. 
distorted copyright analysis elsewhere. Finally, we use the insights from that international study and Aereo to identify what the "right" questions might be.

When Aereo began offering subscribers online access to broadcast TV in 2012, the peculiarities of its technical design attracted immediate attention. It set up arrays of thousands of thumbnail-sized antennae in its Brooklyn warehouse, and based its system around unique copies which were made regardless of whether a subscriber requested to "watch" a broadcast (for near-live viewing) or to "record" it (for future consumption). When a subscriber launched a request for either service, Aereo's servers would allocate her one of those tiny antennae. ${ }^{1}$ The servers would then instruct the antenna to tune in to the relevant broadcast frequency and create a new directory in which to store the recording. ${ }^{2}$ If 10,000 users all requested the same program be recorded, 10,000 tiny antennae would independently tune in, and 10,000 unique copies would be made. ${ }^{3}$ Since Aereo typically assigned users a new antenna for each transaction, many individuals would access the same antenna over time. ${ }^{4}$ However, no two users were ever assigned the same antenna simultaneously, and recordings made while an antenna was assigned to a particular user were never available to anyone else. ${ }^{5}$ If a user selected 'watch', recordings would be automatically discarded after viewing (unless she later chose to keep it); 'recorded' programs would be retained. ${ }^{6}$ Playback from each unique copy could be initiated as it was being made (ie while the program was still airing). ${ }^{7}$

To the uninitiated, it makes no sense for a company to design a television transmission service that utilises thousands of tiny antennae and thousands of copies to deliver signals to users. Wouldn't it be much more efficient to use just one of each? And surely, when it comes to copyright liability, wouldn't more copies result in more infringement, not less? Viewed through the prism of US copyright law, however, Aereo's strategy made a lot of sense. As we demonstrate below, ancillary considerations relating to how the service was designed, who made the copy, and who received the transmission could determine liability, leaving little room for principled considerations of whether the particular act in question ought to be permitted. Aereo's design was a rational response to this legal

Am. Broad. Cos., Inc. v. Aereo, Inc., 874 F. Supp. 2d 373, 377 (S.D.N.Y. 2012).

Id. at 378 .

It appears that three different copies of each program are actually made, of different quality, allowing users to choose the one best suited to the internet connection they're using. Hearst Stations Inc. v. Aereo, Inc., No. 13-11649-NMG, 2013 WL 5604284, at*1 (D. Mass Oct. 8, 2013).

4 Note however that users with 'static' subscriptions are generally assigned the same antennas on an ongoing basis. See id. at 377-78

Id. at 378 .

Am. Broad. Cos., Inc. v. Aereo, Inc., 874 F. Supp. 2d 373, $377-78$ (S.D.N.Y. 2012).

Id. at 377. 
framework: an attempt to exploit the contours of the existing law to enable the service to deliver copyrighted content online without infringing any of the owners' exclusive rights.

This article considers the challenges the Aereo controversy posed and argues that US judicial interpretations that have focused on the "wrong" questions in analysing liability for copyright infringement encouraged Aereo's business model. We then discuss the Supreme Court's recent decision that Aereo's transmission of signals "near-live" does fall within the scope of the right of public performance, and argue that, in correcting the Second Circuit's erroneous inquiries, the Supreme Court raised some "wrong" questions of its own. Later, we examine the legal responses to Aereo's international predecessors in Singapore, Japan, Australia, Germany, France and the EU to determine whether similarly "wrong" questions have distorted copyright analysis elsewhere. Finally, we use the insights from that international study and Aereo to identify what the "right" questions might be.

\section{Part 1: The pre-Aereo law (and its focus on the "wrong" questions)}

Aereo's service implicates two of the copyright owner's exclusive rights - of reproduction and of public performance. ${ }^{8}$ This section builds the case that, before Aereo, judicial interpretations of the scope of each of those rights directed courts to look at the "wrong" questions in determining liability. We define "wrong" questions as those which render the law vulnerable to "avoision" - conduct, combining aspects of law "evasion" and "avoidance", which exploits "the differences between a law's goals and its selfdefined limits". ${ }^{9}$ As we will see, those questions tend to relate to ancillary considerations such as how a service is designed. The "right" questions, by contrast, allow courts to engage in principled consideration of whether a particular use should come within or fall outside the copyright owner's exclusive rights, regardless of the technical means employed.

At the time of writing, the only part of the case against Aereo to have proceeded to judgment concerns issuance of a preliminary injunction against providing access to streams of "near-live" television. Thus, the only "wrong" questions to have been asked so far in that litigation concern the scope of the right of public performance. However, it is nonetheless useful to identify the "wrong" questions in the context of the reproduction

8 See 17 USC $\S 106(1)$, (4). The case against Aereo more broadly claims that Aereo has engaged in direct and contributory infringement of the public performance and reproduction rights. Am. Broad. Cos., Inc. v. Aereo, Inc., 874 F. Supp. 2d 373, 376 (S.D.N.Y. 2012). However, the reproduction right and contributory infringement claims have not yet proceeded to judgment.

9 Tim Wu, "When Code Isn't Law" 89 Virginia Law Review 679, 692 (2003). See also Leo Katz, IllGotten Gains: Evasion, Blackmail, Fraud and Kindred Puzzles of the Law (University of Chicago Press, Chicago, 1996). See also Susy Frankel, "The International Copyright Problem and Durable Solutions," 15 Vanderbilt J. Ent. And Tech. L.(forthcoming 2015). 
right because their existence explains Aereo's design. They also reveal why, in a case involving so many copies, the plaintiff broadcasters chose to focus their attack on the right of public performance.

\section{The right to reproduce the work in copies}

Copies of broadcasts were made when users instructed Aereo's system that they wished to "watch" or "record" a show. In determining whether these copies infringed the broadcasters' reproduction rights, the key preliminary question has been, "who made them?"

The answer to that question determines who may face direct liability for infringement of the reproduction right - and whether liability exists at all. Current US law tends to apply less favorably to commercial service providers who do an act on a user's behalf than to the user herself. ${ }^{10}$ Thus, for example, a user might be entitled to make free copies of material for non profit educational uses under the fair use exception, but a for-profit copy shop making exactly the same copies on the user's behalf would be liable for infringement. $^{11}$

If the court finds that the user committed the allegedly infringing act, the court will next address the affirmative defense that the fair use doctrine entitles the user to make the copies (or otherwise engage in prima facie infringing conduct). If the user's act is deemed a fair use, then courts do not consider whether the service provider's contribution to the commission of the act should be permitted for free. Logically, there can be no liability for enabling the commission of a lawful act. Thus, if Aereo's users "made" the copies, the broadcasters would have to persuade a court to distinguish that conduct from the consumer uses of Sony's Betamax VCR to timeshift free broadcast television programming, uses the Supreme Court in 1984 held were fair. ${ }^{12}$ By contrast, if Aereo

10 Jane C. Ginsburg, Recent Developments in US Copyright Law - Part II, Caselaw: Exclusive Rights on the Ebb? 17 (Columbia Pub. Law \& Legal Theory, Working Paper No. 08158, 2008); William F. PATRY, PATRY ON FAIR USE § 7:3 (2014).

11 See, e.g., Basic Books, Inc. v. Kinko's Graphics Corp., 758 F. Supp. 1522, 1531-32 (S.D.N.Y. 1991); Princeton Univ. Press v. Mich. Document Servs., Inc., 99 F.3d 1381 (6th Cir. 1996). However, courts have been more willing to find that uses on behalf of third parties are fair where they are done for non-profit purposes. See e.g., Cambridge Univ. Press v. Becker. 863 F. Supp. $2 d 1190$ (N.D. Ga. 2012) (reversed on other grounds) (in which a Georgia district court held that the creation of electronic coursepacks by a nonprofit educational institution for nonprofit educational purposes was fair use); Williams \& Wilkins Co. v. United States, 487 F.2d 1345 (Ct. Cl. 1973) (in which it was held that photocopying by the library of the National Institutes of Health of scholarly articles on behalf of members was fair use).

12 See Brief for Respondents at 36-37, Am. Broad. Cos., Inc. v. Aereo, Inc., No. 13-461, (Mar. 26, 2014), 2014 WL 1245459, at *36-37; Sony Corp. of Am. v. Universal City Studios, Inc., 464 U.S. 417 (1984). See infra TAN xx for discussion of whether Sony remains persuasive in the digital environment. 
"made" the copies, the arguable fair use entitlement of Aereo's customers to make the copies would be irrelevant; as the for-profit party committing the unauthorized act of reproduction, Aereo would clearly be an infringer.

The answer to "who makes?" also has important follow-on consequences. A person who does not herself engage in the legally relevant act, but encourages or contributes to someone else's infringement, may nonetheless incur secondary liability for that act. The principles governing the accrual of liability in such cases consider the nature and extent of the provider's contribution, and have been carefully calibrated in an attempt to preserve technologies with substantial non-infringing uses from secondary liability. If the subscriber's deliberate act is instead attributed to the technology provider, that provider may be liable under the broader principles governing direct infringement, without the safety valves that have accompanied secondary infringement analysis.

For each of these reasons Aereo had strong legal incentives to design its service in a way that prompted the conclusion that the user, rather than the service, made the copies. The precedent set by the Second Circuit Court of Appeals in Cartoon Networks $v$ CSC Holdings strongly suggested that Aereo could do so. The technology there at issue was Cablevision's "Remote Storage DVR System" (RS-DVR), which worked the same way as a regular DVR, except that, instead of recording the programming onto the hard disk of a device in the consumer's home, the service would record the content onto a customer's allotted storage space on one of Cablevision's central servers, and stream the programming back on demand. ${ }^{13}$ The Second Circuit held that, "[i]n determining who actually 'makes' a copy, a significant difference exists between making a request to a human employee, who then volitionally operates the copying system to make the copy, and issuing a command directly to a system, which automatically obeys commands and engages in no volitional conduct." 14 Though noting that Cablevision's discretion over the programming that it was making available for recording made its conduct "more proximate" to the creation of the copies than merely operating an ISP, the court concluded that Cablevision's involvement was not enough to justify a finding that Cablevision was itself a "maker" of the copies. ${ }^{15}$

This reference to "volition" can be traced to the 1995 district court decision in Religious Technology Center $v$ Netcom. ${ }^{16}$ There, the court declined to hold an ISP or bulletin board provider directly liable for its facilities' automatic reproduction of a copyrighted work that one of its users had posted. The court reasoned that, despite copyright infringement's

13 Detailed descriptions of the Cablevision RS-DVR are set out at Twentieth Century Fox Film Corp. v. Cablevision Sys. Corp., 478 F. Supp. 2d 607, 612 (S.D.N.Y. 2007); see also Cartoon Network v. CSC Holdings, Inc., 536 F.3d 121, 124-25 (2d Cir. 2008).

14 Cartoon Network v. CSC Holdings, Inc., 536 F.3d 121, 132 (2d Cir. 2008).

15 Cartoon Network v. CSC Holdings, Inc., 536 F.3d 121, 132 (2d Cir. 2008).

16 Religious Tech. Ctr. v. Netcom On-Line Commc'n Servs., 907 F. Supp. 1361 (N.D. Cal 1995). 
strict liability standard, "there should still be some element of volition or causation which is lacking where a defendant's system is merely used to create a copy by a third party."17 The Fourth Circuit subsequently endorsed that distinction in a case involving an internet service provider whose subscribers uploaded infringing photographs to its servers. ${ }^{18}$ In Cartoon Network, the Second Circuit significantly expanded the ambit of the volition criterion from passive communication of third party content to proposing content to copy at the user's behest.

It should now be clear why Aereo designed its system to rely on copies. Under the Cartoon Network template, those copies would be made by the service's subscribers. If so, Aereo believed there was a strong case for those copies being unremunerable fair uses in accordance with the U.S. Supreme Court's 1984 holding that consumer uses of Sony's Betamax VCR to timeshift free broadcast television programming are lawful. ${ }^{19}$ If that were so, none of those copies would give rise to direct liability (and there would be no infringement for which Aereo might potentially be held secondarily liable).

Why "who makes?" is the wrong question

As this analysis demonstrates, a great deal hangs on the answer to the question, "who makes?" In the case of Aereo, if the user made the copies then there is potentially no copyright liability at all (with no consideration given to whether the service provider's contribution to the commission of the act should be permitted for free). If it is the service provider, all of the copies would likely be infringing (with little room to consider whether the subscriber's ultimate use ought to be permitted). Such black-and-white distinctions may have been suitable and appropriate in the pre-digital world, where technologies required much more human input, making it easier to determine each party's contribution to the act. Today however, technology provides us with ever-more sophisticated assistance, making it much more difficult to separate the contributions of the service provider and the user. For example, we use backup software that automatically scans our hard drives for new content, and uploads copies to the cloud for safekeeping. ${ }^{20} \mathrm{We}$ use DVRs that helpfully record shows for us (without our asking) based on programs we've

$17 \quad$ Id. at 1370.

18 CoStar Group, Inc. v. LoopNet, Inc., 373 F.3d 544, 550 (4th Cir. 2004)).

19 See Brief for Respondents at 36-37, Am. Broad. Cos., Inc. v. Aereo, Inc., No. 13-461, (Mar. 26, 2014), 2014 WL 1245459, at *36-37; Sony Corp. of Am. v. Universal City Studios, Inc., 464 U.S. 417 (1984). However, see Rebecca Giblin \& Jane C. Ginsburg, We (Still) Need to Talk About Aereo: New Controversies and Unresolved Questions After the Supreme Court's Decision (forthcoming, 38 Columbia Journal of Law \& the Arts (2015)) at 37-38 of pre-publication copy (arguing that the fair use case is by no means clear cut). See also infra TAN xx for analysis of differences between the Betamax, and "timeshifting" in the current digital environment.

20 See e.g. the Mozy backup software; http://mozy.com/product/features/online-backup. 
previously enjoyed. ${ }^{21}$ As technology evolves still further, judicial determination of who actually engages in the legally relevant act will require the making of increasingly finegrained and potentially unhelpful distinctions Our discussion of the Supreme Court's response to Aereo will identify examples of these sorts of distinctions. We will also see that such distinctions can lead to avoision: making the legal outcome depend on "who does the act?" simply incentivises technology providers to design their services so that the answer is "the user". Yet the act itself may ultimately result in the same market harm whether the answer is "the user" or "the service provider." Thus, when so much hangs on the answer to the "who does?" question, and when the distinctions relied upon to support one conclusion or the other are so arbitrary, it should be clear that "who does?" is the wrong question.

\section{Transmissions}

In the case of liability for public performance, it is even more starkly apparent which questions are the "wrong" ones. The Copyright Act defines "perform" as "to recite, render, play, dance, or act [the work], either directly or by means of any device or process, or, in the case of a motion picture or other audiovisual work, to show its images in any sequence or to make the sounds accompanying it audible." ${ }^{22}$ Courts have ruled that a "performance" must be "simultaneously perceptible;" this condition puts downloads (viewed after their transmission) outside the scope of the right. ${ }^{23}$ The definition of "to perform publicly" has two limbs. To perform or display a work "publicly" means-

(1) to perform or display it at a place open to the public or at any place where a substantial number of persons outside of a normal circle of a family and its social acquaintances is gathered; or

(2) to transmit or otherwise communicate a performance or display of the work to a place specified by clause (1) or to the public, by means of any device or process, whether the members of the public capable of receiving the performance or display receive it in the same place or in separate places and at the same time or at different times. ${ }^{24}$

The act defines to "transmit" a performance or display of the work as meaning "to communicate it by any device or process whereby images or sounds are received beyond

See "TiVo Suggestions"; http://support.tivo.com/app/answers/detail/a_id/205.

17 U.S.C.A. § 101 (West, current through P.L. 113-66).

U.S. v. Am. Soc. of Composers, Authors, Publishers, 627 F.3d 64 (2d Cir. 2010).

17 U.S.C.A. § 101 (West 2010). 
the place from which they are sent." "Devices" and "processes" expressly include those developed after the law came into effect. ${ }^{25}$

The discrete definitions of public performance aim at two very different activities. The first seeks to capture performances which are in public. The second targets performances transmitted to a place we would think of as "private" (for example, viewers' homes), but which nonetheless target "members of the public" and are therefore to the public. In the case of performances transmitted to the public for receipt in private places, caselaw and secondary authority establish that a "substantial number of persons" need not in fact have received the transmission; rather it suffices that the performance of the work be offered to "members of the public." 26

For identifying the "wrong" questions asked in ascertaining infringement of the public performance right, the starting point once again is Cartoon Network v. Cablevision. While the Cablevision system closely resembled a traditional home recording service (which does not implicate the public performance right), its streaming of content on demand to users made it also resemble video-on-demand (which does). Was the cable company engaged in infringing public performances when it streamed the recordings back to its subscribers?

To reach its conclusion, the Second Circuit had to identify the relevant performance. By stating that " $[\mathrm{t}] \mathrm{o}$ perform . . . a work 'publicly' means . . . to transmit or otherwise communicate a performance . . of the work . . . to the public", the statute defines the act of transmitting a performance as one type of performing, even though the terms "to perform" and "to transmit" are separately defined as well. Was the relevant performance the performance created by the act of the transmission (as argued by Cablevision) or the performance of the underlying work (as favored by the broadcasters)?

The Second Circuit ultimately held that, in the context of transmitting a performance to the public, Congress was referring "to the performance created by the act of

25 See, e.g., H.R. Rep. No. 94-1476, $94^{\text {th }}$ Cong. 2 d sess. at 64 (1976)): “The definition of 'transmit' . . is broad enough to include all conceivable forms and combinations of wires and wireless communications media, including but by no means limited to radio and television broadcasting as we know them. Each and every method by which the images or sounds comprising a performance or display are picked up and conveyed is a 'transmission,' and if the transmission reaches the public in [any] form, the case comes within the scope of clauses (4) or (5) of section 106."; H.R. Rep. No. 90$83,90^{\text {th }}$ Cong., $1^{\text {st }}$ sess. at 29 (1967): the legislation anticipates "the case of sounds or images stored in an information system and capable of being performed or displayed at the initiative of individual members of the public.".

26 Some authorities have also pointed out the commercial character of transmissions held to have been made to "members of the public," see, e.g., On Command Video Corp. v. Columbia Pictures Indus., 777 F. Supp. 787 (N.D. Cal. 1991). In Cablevision and in dissent in Aereo, Judge Chin cited the commercial character of the relationship to buttress his determination that the transmissions were to "paying strangers," and thus "to the public." See Twentieth Century Fox Film Corp. v. Cablevision Sys. Corp., 478 F. Supp. 2d 607, 623 (S.D.N.Y. 2007); WNET, Thirteen v. Aereo, Inc., 722 F.3d 500, 505 (2d Cir. 2013) (Chin, J., dissenting). See Giblin \& Ginsburg, supra note 1, text at notes 159-63. 
transmission. ${ }^{27}$ Having accepted that the transmission was the relevant performance, the Second Circuit then considered which members of the public were capable of receiving that performance. It held that, since each transmission was made to a specific subscriber from her own copy, the audience of each transmission was just a single individual, and therefore the relevant performances could not possibly be "to the public". ${ }^{28}$

Why whether the transmission originates from a unique copy and goes to a single individual is the "wrong" question

In the Second Circuit's analysis, the key question was whether the transmission originated from a unique copy and went to a specific individual. The Second Circuit's holdings suggest that, regardless of the nature of the relationship between the recipient and the content, there can be no public performance where the service structures the transmission so that it can be received by only one person.

By basing the standard on the number of possible recipients of each transmission, and by acknowledging, by contrast, that a service whose transmissions emanated from a single centralized copy would be liable, the court focused on technological design rather than on principled considerations of whether the particular use ought to be permitted. It encouraged "avoision" by telling providers that, by making technologically inefficient decisions, they can avoid the liability that would accrue to a more efficient technology facilitating precisely the same end result. Asking how many people can receive a given transmission thus is a "wrong" question because it focuses on extraneous considerations without capturing the essence of the distinction between "public" and "non public" performances. Perhaps the number of persons capable of receiving a transmission from a single source copy was a relevant consideration back in 1984, when a court referred to successive viewers of a single copy to explain that a video store was engaging in "public" performances when it played a single copy of a film multiple times to different small groups of members of the public. ${ }^{29}$ However, in an environment in which it is possible cheaply to assign each subscriber her "own" copy, thus ensuring that the same copy does not serve successive viewers, to base the analysis of the "public" character of a transmission on the number of people permitted to access transmissions from a given source copy simply invites technological manipulations.

In fairness to the Second Circuit, its focus on the wrong questions might have derived from the matter's procedural history. The parties reached a deal to leave certain issues off the table in the litigation between them; the plaintiff broadcasters did not allege

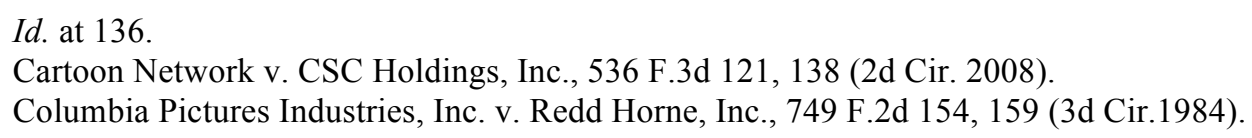


Cablevision's liability for secondary infringement, and in exchange, Cablevision waived any defenses based on its customers' possible fair use. ${ }^{30} \mathrm{Had}$ the case been fully argued, the Court might have decided the case on other aspects of the copyright framework. As it was however, its resolution of the case, with its focus on the "wrong" questions, provided fertile ground for avoision.

\section{Part 2: Asking the wrong questions of Aereo}

As explained above, the only aspects of the Aereo controversy so far to have been adjudicated concern whether Aereo should be enjoined from providing access to broadcast television (during the initial broadcast) on the grounds that its service violates the right of public performance. Here, we examine how the lower courts and ultimately the Supreme Court confronted Aereo's challenge to the reach of the public performance right.

\section{The lower court decisions}

Applying Cartoon Network v. Cablevision, the district court and a divided Second Circuit each concluded that Aereo had not "publicly performed" the television programs. ${ }^{31}$ The appeals court majority reiterated its view that "the relevant inquiry under the Transmit Clause is the potential audience of a particular transmission, not the potential audience for the underlying work or the particular performance of that work being transmitted."32 It also held that "two essential facts" led to the holding that Cablevision's transmissions were not public performances: Cablevision's RS-DVR allowed each subscriber to create unique copies of each program, and the subscriber's unique copy was the source of the transmission back to the subscriber. ${ }^{33}$ These features meant that "the potential audience of every RS-DVR transmission was only a single Cablevision subscriber, namely the subscriber who created the copy;" thus restricted, the transmission was not "to the public". ${ }^{34}$ Aereo's system emulated those two features. ${ }^{35}$

The dissenting judge charged that Aereo's technical architecture was "a sham":

The system employs thousands of individual dime-sized antennas, but there is no technologically sound reason to use a multitude of tiny individual antennas rather than one central antenna; indeed, the system is a Rube Goldberg-like contrivance,

Cartoon Network, 536 F.3d at 124.

874 F. Supp. 2d 373 (S.D.N.Y. 2012); WNET, Thirteen v. Aereo, Inc., 712 F.3d 676 (2d Cir. 2013).

WNET, Thirteen v. Aereo, Inc., 712 F.3d 676, 691 (2d Cir. 2013).

Id. at 689 .

Id. at 689-90 (citations omitted).

Id. at 690 . 
over-engineered in an attempt to avoid the reach of the Copyright Act and to take advantage of a perceived loophole in the law. ${ }^{36}$

The majority retorted that many other technology providers, particularly cloud computing services, had also designed their systems around Cablevision's holdings. "Perhaps the application of the Transmit Clause should focus less on the technical details of a particular system and more on its functionality, but this Court's decisions . . . held that technical architecture matters." ${ }^{, 37}$ Acknowledging that it is more difficult to distinguish between public and private transmissions than when Congress enacted the transmit clause in 1976, the majority ultimately concluded that the language of the Act, as previously interpreted in Cablevision, dictated the conclusion that Aereo's transmissions were not public performances. ${ }^{38}$

\section{The Supreme Court's decision}

In determining whether Aereo was liable for infringing public performance, the Supreme Court on ultimate appeal asked two questions: first, did Aereo perform at all? Second, if it did, were those performances "to the public?"

\section{Did Aereo perform?}

The Second Circuit in Cartoon Network and Aereo never determined who engaged in the relevant performance, because its findings that the unique copy architecture prevented any of those transmissions from being "to the public" made it unnecessary to do so. However, the Supreme Court did confront this issue.

The six justice majority (Breyer, joined by Roberts, Kennedy, Ginsburg, Sotomayor and Kagan) held that Aereo had indeed performed the relevant act. Though noting the Act does not delineate between entities which themselves "perform" and those which merely supply equipment enabling others to do so, the majority found that, "read in light of its purpose, the Act is unmistakable: An entity that engages in activities like Aereo's performs." 39 In analysis that did not mention the concept of volition at all, the majority reasoned:

Aereo's activities are substantially similar to those of the CATV companies that Congress amended the Act to reach... Aereo sells a service that allows subscribers to watch television programs, many of which are copyrighted, almost as they are being broadcast. In providing this service, Aereo uses its own

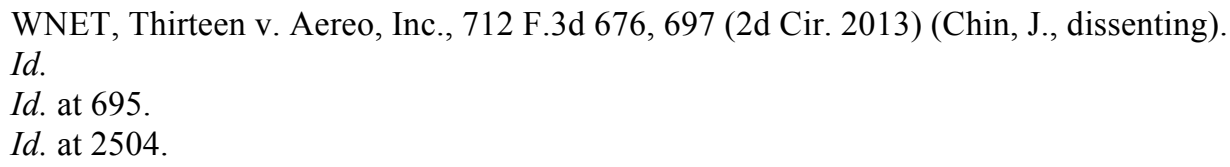


equipment, housed in a centralized warehouse, outside of its users' homes. By means of its technology (antennas, transcoders, and servers), Aereo's system "receive[s] programs that have been released to the public and carr[ies] them by private channels to additional viewers." 40

This holding is a narrow one. It instructs that a technology provider may itself perform when it is sufficiently analogous to a CATV operator, but provides little guidance about whether and when, outside those circumstances, a technology provider will be sufficiently involved in the infringement to justify the imposition of direct liability.

The three justice dissent (Scalia, joined by Thomas and Alito) objected that Aereo lacked sufficient volition to be the one "performing" the programming. ${ }^{41}$ Accordingly, these justices found it unnecessary to go on to consider whether the performance was "to the public". Since the only claim being litigated was that Aereo itself had publicly performed, if Aereo did not "perform," there could be no liability.

\section{Were Aereo's performances "to the public"?}

The majority's analysis proceeded on the basis that the relevant act is the performance of the underlying work (effectively overturning the Second Circuit's statutory interpretation identifying the relevant performance as the transmission to the recipient). ${ }^{42}$ It then held that those performances were "to the public" notwithstanding each transmission's origin in a separate subscriber-assigned copy. In reaching that finding, the court revisited the meaning of "the public". It noted that, although the Act does not define this term, it does specify that an entity performs publicly when it performs at "any place where a substantial number of persons outside of a normal circle of a family and its social acquaintances is gathered." 43 After repeatedly emphasizing the importance of transmissions being made to a "large" group of people in order to be "to the public", the court concluded that "an entity does not transmit to the public if it does not transmit to a substantial number of people outside of a family and its social circle." "44 Thus, the Court used the text of the first limb of the statutory definition of "to perform publicly"

\footnotetext{
$40 \quad I d$. at 2506.

$41 \quad$ Id. at 2514.

42 Although the majority states it assumes, arguendo, that Aereo's argument that the performance is that which arises from the transmission is correct, its application of the law makes sense only if the relevant performance is the performance of the underlying work. See Am. Broad. Cos., Inc. v. Aereo, Inc., 134 S. Ct. 2498, 2508 (2014). Indeed, the court later made that assumption clear: "So whether Aereo transmits from the same or separate copies, it performs the same work; it shows the same images and makes audible the same sounds. Therefore, when Aereo streams the same television program to multiple subscribers, it 'transmit[s] . . . a performance' to all of them." $134 \mathrm{~S} . \mathrm{Ct}$. at 2509.

43 Am. Broad. Cos., Inc. v. Aereo, Inc., 134 S. Ct. 2498, 2509-10 (2014)

44 Id. at 2510-11.
} 
(performance in public) to help it define the meaning of "the public" in the second (transmission to the public). The Court then further narrowed the meaning of "the public" by stating that "those who act as owners or possessors of the relevant product" do not constitute "the public", ${ }^{45}$ and by noting, without further explanation, that "the doctrine of 'fair use' can help to prevent inappropriate or inequitable applications of the [Transmit] Clause. ${ }^{\prime 46}$

How the Supreme Court created new "wrong" questions of its own

The Supreme Court welcomely recognised that, by concentrating on the individual transmissions to subscribers, the Second Circuit had asked the "wrong" question in considering whether Aereo's facts gave rise to any infringing public performance. However, in redefining what it means to perform "to the public", it raised some "wrong" questions of its own.

First, by inquiring whether Aereo "performed," the Court continued to give the question "who does the act?" dispositive significance. Moreover, the Court's way of answering that question is likely to encourage avoision. As we have seen, when "who does the act?" is the predicate question, a court may never assess applicability of exceptions or of principles of secondary liability. Failure to confront the economic concerns that underlie both fair use and contributory infringement may not be problematic where "who does the act?" is readily apparent. But as we noted above, technological advances have made it increasingly difficult to ascertain to whom to attribute the copyright-triggering act, leading to the use of increasingly arbitrary and granular distinctions.

The majority's analysis in Aereo exemplifies this difficulty. The factors which inclined the court to find that Aereo itself transmitted the content (rather than simply enabling its users to do so) focused on Aereo's similarities to 1970s-era cable TV providers. Like those community antenna companies, Aereo's service allowed subscribers to watch nearlive television broadcasts. It used its own equipment, and that the equipment was housed in a centralized warehouse rather than in users' homes. This combination of circumstances led the majority to conclude that Aereo committed the legally relevant acts. $^{47}$

The Supreme Court carefully confined its decision to the facts, and gave no guidance as to when, outside these factors, a provider may face direct rather than secondary liability. The Court's silence portends that future judicial determinations of technology providers' commission of the legally relevant acts will depend too heavily on the relationship of the design of technologies to business models. Reference to analogous technologies

Aereo, 134 S. Ct. at 2510

Id. at 2511

See Am. Broad. Cos., Inc. v. Aereo, Inc., 134 S. Ct. 2498, 2506 (2014). 
demonstrates the arbitrariness of these considerations. For example, Cablevision's RSDVR also utilizes the service provider's own equipment, housed in a centralized warehouse, but it allows programs to be streamed back from recordings only after the broadcast is complete. What, if any, difference does/should delaying the commencement of playback till after completion of the initial broadcast make? (The Court emphatically declined to address whether RS-DVR services "publicly perform" the timeshifted works.) The "Hopper with Sling", a DVR + slingbox provided by a major satellite company in the US, allows the transmission of near-live TV broadcasts via equipment owned by the satellite company, but located in the user's home instead of in a centralized warehouse. What, if any, difference does/should locating the recording and transmission equipment in the subscriber's home rather than in the service's facilities make?

Our analysis in earlier work demonstrates that, under the Supreme Court's reasoning, such details of location, ownership and technological design may in fact make the difference between legality and infringement - even if the ultimate act remains the same. ${ }^{48}$ We also suggested that making these differences outcome-determinative was undesirable. Courts' emphasis on these details creates obvious new incentives for avoision: a service provider, seeking to accomplish an act which would be infringing if done by the service, but permitted if done by the user, will rationally design its technology to assign "actor" attribution to the user. Thus the law (rather than the nature of the services the technologies deliver) may dictate the design of future technologies. For example: online access to remote equipment is cheap and efficient, and can result in improved access for individuals who cannot afford to purchase it outright. But the Supreme Court may have incentivised future providers to design products that are owned by consumers and based in their homes - even though considerations of location and ownership say nothing about the desirability or harm of the underlying use.

The Supreme Court also asked the "wrong" questions in determining when a performance is "to the public". One of the "wrong" questions that the Second Circuit in Cartoon Network had asked was whether the transmission originates from a unique copy and goes to a specific individual. The Second Circuit's holding suggested that there can be no public performance where the service structures the transmission so that it can be received by only one person, regardless of the nature of the relationship between that person and the content. The Supreme Court correctly ruled that this was not the right question. However, its own definition of what it means to perform "to the public" was not entirely successful either.

As noted above, the majority repeatedly emphasized that the transmission be made to a "large" group of people in order to be "to the public." Moreover, it declared that "an

48 Rebecca Giblin \& Jane C. Ginsburg, We (Still) Need to Talk About Aereo: New Controversies and Unresolved Questions After the Supreme Court's Decision (forthcoming, 38 Columbia Journal of Law $\&$ the Arts (2015)); at 18-22; 24-28 of pre-publication copy. 
entity does not transmit to the public if it does not transmit to a substantial number of people outside of a family and its social circle." 49 It seems likely that the majority imported that size requirement into the latter analysis to avoid problems of overinclusivity arising from its ruling that the relevant act was the performance of the underlying work (rather than the individual transmission). But importing a size requirement into the transmit clause misses the essence of the statutory distinction between public performances (encompassed within the copyright owner's exclusive rights) and non-public performances (to which exclusive rights do not extend): size is a proxy for economic significance; in most cases (at least under prior technologies) a transmission offered to a small group of persons, or to members of a family and its social acquaintance, would not have significantly intruded on the copyright owner's markets for publicly communicating performances of the work. But size is not a value of its own, and the omission of a size of audience criterion from the text of the transmit clause (unlike the performance "in public" clause) should be taken seriously. What matters is whether the offeree of the transmission is a "member of the public," not how many members of the public are "capable of receiving" the transmission. The omission of a size threshold from the transit clause enables the public performance right to adapt to changing market conditions as the means and granularity of transmissions evolve.

Instead, the court's definition of "the public" creates a gap in the scope of the public performance right that invites new business models for delivery of performances of works. A novel suggestion proposed by the Wall Street Journal for reducing cable bills in the wake of Aereo - sharing a single cable subscription between two households by utilizing a Slingbox - proves the point. One household would have legitimate access to the cable content via a paid subscription, and would "sling" the content to the other, giving access to the content without ever making any copies. The second household could watch whatever it liked unless the first household was watching too; in that case, it would be limited to the same programming-and have no recourse if the person operating the remote control in the subscribing household decided to change the channel halfway through Homeland's season finale. The WSJ writer argued this arrangement was legal since "this stream goes from one cable connection to just one outside device."

But transmissions even to a small audience can interfere significantly with licensed markets. Think about how the arrangement proposed by the WSJ might spread. The "sharing economy" is all the rage at the moment, connecting those who have unused resources with those who seek them. AirBnB, for example, creates a market for households to rent out their spare rooms. Uber joins those who need a ride with those who have a car. Households with cable subscriptions might readily reach agreement with friends or relatives to share those, too. And the cable-equipped households could add

$49 \quad$ Id. at $2510-11$.

50 http://online.wsj.com/articles/getting-rid-of-cable-tv-the-smartest-ways-to-cut-the-cord-1405472757 
more functionality by attaching the slingbox to a secondary set-top box, allowing both households to have full access to the subscribing household's content without limiting anyone's viewing choices. ${ }^{51}$ Since they're non rivalrous in consumption, TV signals could be the ultimate contribution to the "sharing economy".

We caution, however, that Aereo should not spawn "sharing economy" brokerage services, akin to Air BnB or Uber. A household that offers unused cable service to a friend limits not only the transmission but also the offer to one other person. By contrast, an "Uber for cable TV" service offers the surplus cable service to the public in general, even though only one household will in fact receive the shared cable transmissions. Properly understood, Aereo's definition of "the public" refers to the public to whom the transmission is proposed. If the brokerage service is putting the sharing household together with the first-comer who replies to an offer made to members of the public at large (or, for that matter, to members of a more narrowly defined "public," such as fans of Homeland), the transmissions are "to the public." 52 Of course, the Aereo court did not confront such scenarios, but the posited, unbrokered, arrangement indeed appears to be consistent with the court's statements, to the extent they exclude transmissions that the person engaging in the performance offers to only a small group or to a single individual. Applying Aereo, the performances would be engaged in by the householder providing and hosting the equipment and signal. But the performances would not be "to the public" under the majority's reasoning, because they would not have been offered to a "large or substantial" number of people, even though the cumulative impact on rightholders were many people to adopt this practice could be severe. Aereo's concept of "the public," as currently articulated, seems insufficiently nuanced to confront situations involving individual performances to small audiences that cumulatively interfere with markets for licensed alternatives. Moreover, once an avenue of exploitation opens, many will surely follow it; the more widespread the activity, the more difficult it may later become to interpret the copyright act to restrict the practice. Thus, the court's reasoning may open the door to some of the same kind of "avoision" or technological exploitation that it was intended to redress.

\section{Part 3: Do other jurisdictions focus on the "wrong" questions too? Aereo-style business models abroad}

http://support.slingbox.com/KB/KB-2000571 'Using Sling'.

In this scenario, the "maker" of the transmissions would be the householder, not the broker through whom the householder offers to share the subscription with a member of the public. But the broker would likely be secondarily liable for contributing to or inducing infringement. Other scenarios might involve intermediaries whose participation might be deemed too attenuated to warrant secondary liability, such as the operator of a "Craigslist" type website that featured a general "sharing economy" category of listings, not broken down into categories sufficiently specific to suggest knowledge of what is being "shared." 
In our analysis above, we argue that the US law (both before and after Aereo) asks several "wrong questions" in determining liability. Aereo is not the first business to have sought to facilitate copyright-free communications by assigning individual copies of broadcast or cable-transmitted content to requesting subscribers and then retransmitting the content exclusively to that subscriber from "her" copy. It has a number of entrepreneurial predecessors that have been tested in the courts of other jurisdictions. In this section we canvas that history to see both whether the wrong questions are being asked elsewhere too, and if we can glean some lessons for determining what the right questions might be.

\section{Singapore}

The key authorities in Singapore stem from litigation against RecordTV's "iDVR" service. The iDVR service did not initially make multiple unique copies when multiple subscribers requested the same program to be recorded, but it began migrating to a multiple copy architecture during the course of the Cartoon Network litigation, and had begun using this method exclusively within a month or two of the Second Circuit's decision. ${ }^{53}$ In other essential respects the Singaporean service closely resembled Cablevision's RS-DVR. ${ }^{54}$ In response, the nation's largest broadcaster claimed that RecordTV's service infringed its exclusive rights relating to copying and electronic communication.

Under Singaporean law, copyright owners have the exclusive right to "communicate to the public", with "communicate" defined to mean:

to transmit by electronic means (whether over a path, or a combination of paths, provided by a material substance or by wireless means or otherwise) a work or other subject-matter, whether or not it is sent in response to a request, and includes -

$\cdots$

(c) the making available of a work or other subject-matter (on a network or otherwise) in such a way that the work or subject-matter may be accessed by any person from a place and at a time chosen by him. ${ }^{55}$

The Act further provides that "a communication other than a broadcast is taken to have been made by the person responsible for determining the content of the communication at the time the communication is made." 56

Singaporean law also provides that there is no infringement of the copyright in a TV or cable broadcast (or any underlying work) where a user makes copies for her "private and domestic use." ${ }^{, 57}$ These copies were not unremunerated: at the time the case was brought,

\footnotetext{
53 RecordTV v MediaCorp TV Singapore [2011] 1 SLR 830, 836.

54 RecordTV Pte Ltd v MediaCorp TV Singapore Pte Ltd [2010] 2 SLR 152, 157-158; RecordTV v MediaCorp TV Singapore [2011] 1 SLR 830, at 833-836.

Copyright Act 1987 (Singapore), s 7.

Copyright Act 1987 (Singapore), s 16(6).

Copyright Act 1987 (Singapore), s 114.
} 
Singaporean households were obliged to pay an annual licence fee in exchange for receiving TV signals. The Court of Appeal read the exception as allowing those with valid licences to make copies of those programs as well. ${ }^{58}$

The wording of the private copying exception made it crucial to determine who made the copies: if the service, then the service would infringe, but if the user, the exception would apply. In analysis heavily influenced by the Second Circuit's holdings regarding "volition", the Court of Appeal held that the copies were made by the subscribers, not the service, and therefore there was no infringement. ${ }^{59}$

There was no liability under the electronic communication right either, for two reasons. First, the users who had requested the recording be made and then communicated to them did not constitute "the public" within the meaning of the Act. ${ }^{60}$ Though "the public" is not defined, the Court of Appeal found it highly relevant that the only recipient of each recording would be the user or users who had requested it to be made, and saw "no reason why the aggregate of the private and individual communications made to each of the ... Registered Users should transform the nature of such communications into "public" communications." would nonetheless be no liability on these facts because the communication to the subscribers was not "made" by RecordTV. As noted above, under Singaporean law communications are taken to have been made by the person responsible for determining the content of the communication at the time the communication is made. ${ }^{62}$ The Court of Appeal distinguished these facts from situations involving video-on-demand providers who share a library of pre-selected works with users at large.${ }^{63}$ Instead, it reasoned that, because the only works that were "communicated" to an individual user were those he or she had previously selected for recording, it was that subscriber who was responsible for determining the content of the communication at the relevant time, and thus the maker of the communication. ${ }^{64}$

\section{Are these the right questions?}

As this summary demonstrates, even more hangs on the answer to "who makes?" under Singaporean law than in the US. Under US law, whether the user has the right to make copies of broadcast TV signals depends on whether the use is "fair"; that requires consideration of factors such as the effect of the use upon the potential market for the work. ${ }^{65}$ Under Singaporean law however, private copies of TV or cable broadcasts can be made regardless of such considerations. Thus, the "winner takes all" - if the maker of the copies is the user, the copying is permitted (with no room to consider whether that outcome is appropriate given the extent of the service provider's contribution); if the

\footnotetext{
$58 \quad$ RecordTV v MediaCorp TV Singapore [2011] 1 SLR 830, 835.

59 RecordTV v MediaCorp TV Singapore [2011] 1 SLR 830, at 838-842.

60 RecordTV v MediaCorp TV Singapore [2011] 1 SLR 830, at 842-845.

61 RecordTV v MediaCorp TV Singapore [2011] 1 SLR 830, at 843.

62 Copyright Act 1987 (Singapore), s 16(6).

63 RecordTV v MediaCorp TV Singapore [2011] 1 SLR 830, at 846.

64 RecordTV v MediaCorp TV Singapore [2011] 1 SLR 830, at 846-847.

65 See 17 USC $§ 107$.
} 
maker is the service provider, the use is infringing (regardless of whether it is appropriate for the individual to be permitted to engage in the use). The consequences of that lack of nuance become apparent in examining RecordTV's current offerings. While the appeals court's finding that the users made the copies was apparently influenced by the licence fees paid by Singaporeans for that content, TV licences were abolished a month after the decision. $^{66}$ RecordTV nonetheless continues to provide its service, and now offers subscribers the opportunity to record single shows, entire series or even their favourite channels nonstop, 24/7. ${ }^{67}$ This service seems to provide a very good substitute for remunerated on-demand access.

Applying the right of public performance, the Court of Appeal suggested that the communications could not be "to the public" because they are made and transmitted to the same person. In any event, it held that they could not be public because each recording was directed only to a single individual. As in Cartoon Network, this reasoning incentivises providers to design their technologies to use individualised transmissions, rather than squarely confronting the essence of "public" versus "non public" communications, and renders the law highly vulnerable to avoision. On both counts, the focus was on the "wrong" questions.

\section{Australia}

Making private copies of television programs was unlawful in Australia until 2006, when a statutory exception finally permitted the making of recordings "solely for private and domestic use by watching or listening to the material broadcast at a time more convenient than the time when the broadcast is made". ${ }^{68}$ As in Singapore, there is no requirement that those uses be "fair". In 2011, telecommunications provider Optus introduced a remote DVR service called "TV Now". ${ }^{9}$ TV Now worked just like Cablevision's RSDVR and Record TV's iDVR: subscribers could request television programs to be recorded by making selections from the online program guide, and subsequently play them back via their web browser or on a mobile device. ${ }^{70}$ Individual copies were made for, and played back exclusively to, each requesting user. Unique recordings for each requesting user were stored remotely on Optus's servers, and then streamed to subscribers' devices on request, sometimes as they were still airing. ${ }^{71}$ The service was explicitly aimed as users who wished to timeshift broadcasts; the service prevented

66 See eg Media Exchange, 'Radio and Television licence abolished' http://www.mda.gov.sg/Documents/Newsletter/Issue06/Pages/01.aspx.html.

67 RecordTV.com (content viewable only from a Singaporean IP address). Screenshot of RecordTV's website offering this feature on file with authors.

68 See Copyright Amendment Act 2006 (Cth) (Australia), Schedule 6, Part 1. For a fuller discussion of the definition see Rebecca Giblin, 'Optus v NRL: A Seismic Shift for Time Shifting in Australia' (2012) 35 European Intellectual Property Review 357, at n19.

69 Singtel Optus v National Rugby League Investments (No 2) [2012] FCA 34, at [2]-[3].

$70 \quad$ Singtel Optus v National Rugby League Investments (No 2) [2012] FCA 34, at [2].

71 Id at [17]. 
librarying by automatically deleting recordings from the remote storage after 30 days, and no copies were made on subscribers' machines. ${ }^{72}$

Sporting organisations and the licensee of their mobile streaming rights quickly sued. Once again, the relevant rights concerned the making of copies and electronic communications. To "communicate" means to make copyrighted protected subject matter available online, or to transmit it electronically. ${ }^{73}$ As in Singaporean law, communications (other than broadcasts) are taken to have been made "by the person responsible for determining the content of the communication." ${ }^{, 74}$

The trial judge found no infringement of the communication right. His starting point was the same as under Singaporean law: the finding that the relevant communications were made by users, not by Optus, since the users were the ones responsible for determining the content of the communication. ${ }^{75}$ (Optus did not "communicate" because "it did nothing to determine the content of that communication., ${ }^{76}$ ) The trial judge then found that the relevant communications were not "to the public". Here however the reasoning diverts interestingly from that in the US and Singaporean cases we've canvassed so far. Australian courts use the notion of the "copyright owner's public" to distinguish between "public" and "private" performances. The "copyright owner's public" is "the group which the copyright owner would . . . contemplate as its public for the performance of its work." "77 This approach originates in a line of UK cases which, in determining whether a performance was "in public," focused on the harm the act causes to the author of the work. ${ }^{78}$ Thus, the essence of a performance "to the public" in Australian law is that it is occurring in circumstances where the owner is entitled to expect payment for the work's authorized performance. ${ }^{79}$

Applying this standard to the facts at issue, the trial judge found it relevant that "a user who made the recording for the protected purpose in s 111(1) and clicked the 'play' button to watch it would ordinarily be doing so for the very private and domestic use for which he or she made the recording, ${ }^{, 80}$ and that users would have been perfectly entitled freely to copy the broadcasts via a VCR or DVR. For these reasons, he concluded that, "the impact of a user communicating the recording or film to his or her compatible device lacks the element of commercial detriment to the rightholders' that is necessary for a transmission to be "to the public". 81

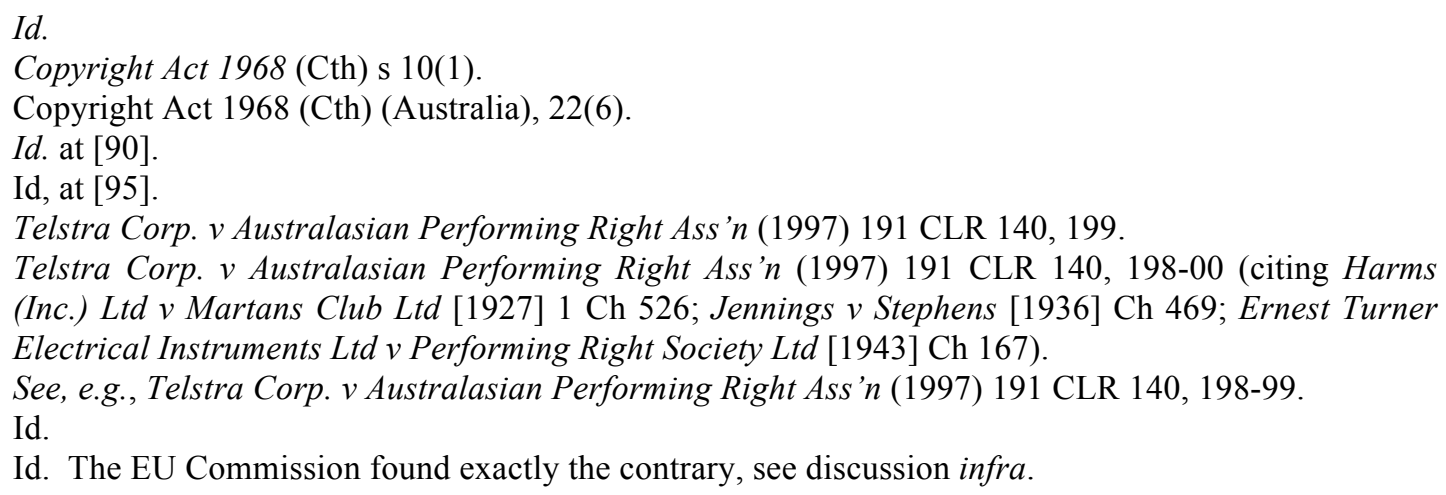


The trial judge found no infringement of the right to copy either. He held that the maker of the copies was the user, because "[i]f the user does not click 'record', no films will brought into existence." 82 His analysis noted that the finding was consistent with the reasoning of the Second Circuit in Cablevision. ${ }^{83}$ Having found that the users made the copies, the trial judge then found that they were protected by the statutory timeshifting exception. $^{84}$

The appeals court did not revisit the issues relating to the communication right, but did overturn the trial judge's findings regarding the right to copy. The Full Federal Court ultimately held that Optus (possibly alone, but probably in conjunction with the user) was the maker of the recorded copies. It described Optus's role in making the copy, by capturing the broadcast and storing it on its servers, as being "so pervasive that, even though entirely automated, it cannot be disregarded when the 'person' who does the act of copying is to be identified." ${ }^{, 5}$ It found that the recording is made only "by reason of Optus' system remaining 'up' and available to implement the subscriber's request at the time when its recording controllers poll the user database and receive a response indicating that a recording has been requested." 86 It rejected the Cablevision-style "volitional conduct" approach to the question of "who makes the copy," finding that it would "require a gloss to be put on the word "make' in the Act." reason why "a person who designs and operates a wholly automated copying system ought as of course not be treated as a 'maker' of an infringing copy where the system itself is configured designedly so as to respond to a third party command to make that copy" ${ }^{88}$ Ultimately the court held that, even if a "volitional conduct" standard were adopted, it would be satisfied by Optus' conduct in "creating and keeping in constant readiness the TV Now system." 89 In its view, Optus wasn't "merely making available its system to another who uses it to copy a broadcast ... Rather it captures, copies, stores and makes available for reward, a programme for later viewing by another."90 As Optus was not protected by the timeshifting exception, it was directly liable for infringement of the reproduction right. ${ }^{91}$

\section{Are these the right questions?}

As in Singapore, the Australian timeshifting exception applies regardless of whether it is "fair" to make those copies. No TV license fee or other remuneration is paid in exchange.

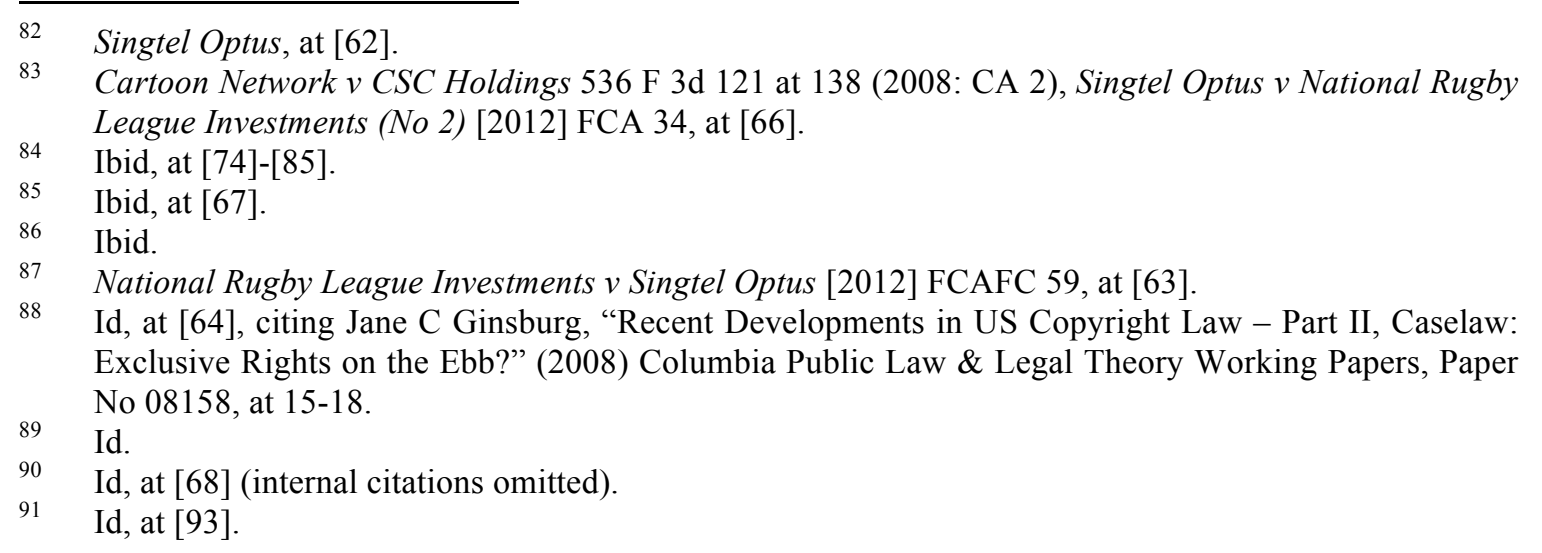


The appeals court seemed strongly of the view that Optus' service, providing "near-live" access, was not in fact fair, which may have influenced it to find that Optus also "made" the copies. Once again, the winner takes all. The copies are infringing and not permitted if the maker is the service; but perfectly lawful if the maker is exclusively the user. Regardless of who is found to make the copy, there is no room in this framework to query whether the particular use ought to be permitted in the circumstances.

The Australian law governing the communication right is much more nuanced than the law relating to copies. Who makes the communication matters much less in this analysis than in the others we've seen so far, because the focus is on the relationship between the copyrighted work and its recipient, not the transmitter and the recipient. By focusing on the harm to the copyright owner's economic interests, this enquiry invites deliberation on a range of considerations relating to the whether the ultimate use should be permitted. It is less vulnerable to avoision than the other interpretations we have canvassed so far, because the size of the audience doesn't matter. Even a transmission from one person to herself may be public in nature if we use the lens of the "copyright owner's public". 92

\section{Japan}

The Japanese copyright owner enjoys exclusive rights (among others) to engage in public transmission of his work, to communicate it publicly and to make reproductions. ${ }^{93}$ These rights are subject to a number of purpose-based exceptions, including one which permits the reproduction of copyrighted works 'for the purpose of her personal use, family use or other similar uses within a limited circle'. ${ }^{94}$ A private copying levy paid by consumers remunerates owners for many of these uses. ${ }^{95}$ Under Japanese copyright law, injunctive relief is reserved for instances of direct infringement; in other cases, damages are the only remedy. ${ }^{96}$ To lessen the impact of this rule, a legal principle known as the 'Karaoke Doctrine' has evolved; it expands the scope of primary infringement to enable a finding of direct infringement where there is sufficient nexus between the service provider and the infringement. ${ }^{97}$ The doctrine originated in a case brought against the owners of a

92 See Rebecca Giblin \& Jane C. Ginsburg, We (Still) Need to Talk About Aereo: New Controversies and Unresolved Questions After the Supreme Court's Decision (forthcoming, 38 Columbia Journal of Law \& the Arts (2015)), 35-36. 41.

93 Chosakuken Hō [Japanese Copyright Act], Law No. 48 of 1970, arts. 23(1) and (2); 21. (English translation available at http://www.cric.or.jp/english/clj/cl2.html).

94 Chosakuken Hō [Japanese Copyright Act], Law No. 48 of 1970, art. 30(1). (English translation available at http://www.cric.or.jp/english/clj/cl2.html).

95 See eg Branislav Hazucha, 'Law, Market and the Role of Courts in Regulating New Technologies and Online Services' http://papers.ssrn.com/sol3/papers.cfm?abstract_id=1427821 p 31.

96 Chosakuken Hō [Japanese Copyright Act], Law No. 48 of 1970, art. 112(1). (English translation available at http://www.cric.or.jp/english/clj/cl2.html). See also discussion within Naoya Isoda, 'Copyright Infringement Liability of Placeshifting Services in the United States and Japan' 7 Wash J. L. Tech. \& Arts 149, 165 (2011); Takashi B. Yamamoto, 'Legal Liability for Indirect Infringement of Copyright in Japan' http://www.itlaw.jp/yearbook35.pdf at 1-4.

97 Takashi B. Yamamoto, 'Legal Liability for Indirect Infringement of Copyright in Japan' http://www.itlaw.jp/yearbook35.pdf at 1 . 
karaoke club. ${ }^{98}$ Its customers used the machines in the club to sing copyrighted songs, and the Court held the club owners themselves directly liable for infringing the performance right on the grounds that they were so closely involved in their customers' acts that 'singing by the guests may be considered to be the same as singing by the petitioners themselves. 99 The Karaoke Doctrine is analogous to the US secondary liability doctrine of vicarious infringement in that liability depends on an ability to oversee or 'manage' the activity and a financial interest in that activity. ${ }^{100}$ However, because it results in primary rather than secondary liability, service providers can be liable for their customers' exploitation of works even where those customers had a right to do so because of an exception within the Act. ${ }^{101}$ Since the Karaoke Doctrine is the only way by which injunctive relief may be obtained against those who facilitate conduct without personally committing infringing acts, courts may be inclined to read it expansively.

A number of cases involving internet transmission of TV shows have made their way through Japanese courts in the last few years. The most relevant to our discussion of Aereo is Maneki TV. ${ }^{102}$ Sony's 'LocationFree' equipment 'slings' TV signals to other locations; the 'base station' of the device receives broadcasts, digitizes them and automatically transmits them to users on demand. ${ }^{103}$ Users can then receive those transmissions on another device via the internet. ${ }^{104}$ Maneki TV's business involved renting space to its customers for the storage of their 'LocationFree' base stations, and then connecting them to a broadcast signal and the internet. ${ }^{105}$ This service was particularly attractive to users wanting to watch Japanese TV while living abroad. Broadcasters argued that the service provider had itself made the transmissions in accordance with the karaoke doctrine, and thus was directly liable for infringement. The Intellectual Property High Court of Japan held there was no public transmission by the defendant because each base station simply transmitted to a single corresponding device,

98 'Club Cat's Eye' decision of the Japanese Supreme Court, 15 March 1988, 42 Minshu Number 3. The development of this doctrine is discussed in detail in Takashi B. Yamamoto, 'Legal Liability for Indirect Infringement of Copyright in Japan' http://www.itlaw.jp/yearbook35.pdf at 9-11.

99 Takashi B. Yamamoto, 'Legal Liability for Indirect Infringement of Copyright in Japan' http://www.itlaw.jp/yearbook35.pdf at 10 citing 'Club Cat's Eye' decision of the Japanese Supreme Court, 15 March 1988, 42 Minshu Number 3.

100 Takashi B. Yamamoto, 'Legal Liability for Indirect Infringement of Copyright in Japan' http://www.itlaw.jp/yearbook35.pdf at 11 .

101 Naoya Isoda, 'Copyright Infringement Liability of Placeshifting Services in the United States and Japan' 7 Wash J. L. Tech. \& Arts 149, 168 (2011); Takashi B. Yamamoto, 'Legal Liability for Indirect Infringement of Copyright in Japan' http://www.itlaw.jp/yearbook35.pdf at 1 .

102 Due to difficulties accessing comprehensive translations of the case, we have relied more on secondary sources than would usually be the case.

103 Maneki TV decision of the Japanese Supreme Court, p1 (from English translation by Haruaki Murao, on file with authors).

104 Maneki TV decision of the Japanese Supreme Court, p1-2 (from English translation by Haruaki Murao, on file with authors); Branislav Hazucha, 'Law, Market and the Role of Courts in Regulating New Technologies and Online Services' http://papers.ssrn.com/sol3/papers.cfm?abstract id=1427821 $\mathrm{p} 10$.

105 Maneki TV decision of the Japanese Supreme Court, p2 (from English translation by Haruaki Murao, on file with authors). 
not to the "public.""106 In 2011, the Supreme Court reversed, holding that a public transmission can occur even if the device transmits only to a single other device, and that "[w] hen said device is connected with a telecommunications line that is provided for use by the public and information is continuously inputted therein, it is reasonable to consider that the actor of the transmission is the person inputting information to said device." 107 Because any subscriber could use the service, the Court was satisfied that those subscribers were "the public."108

At around the same time the High Court was also asked to resolve the legality of a similar technology, the "Rokuraku II." The Rokuraku system had similar functionality to that provided by Maneki TV, but allowed users to make copies as well as "sling" the signal. ${ }^{109}$ The plaintiff broadcasters alleged infringement of their exclusive right of reproduction. Emphasizing that it was the users themselves who chose and initiated the recordings, the High Court found that the service provider had not committed any infringement, but instead was doing "no more than provide an environment that facilitates the reproduction by a user of the Service." 110 The users themselves were not liable either, as their making of the copies was permitted under the personal use exception.

The Supreme Court reversed in this case as well, finding that the service provider was in fact a maker of the copies, even though the subscriber was the only person involved in their selection and initiation:

the Service Provider not only provides an environment that facilitates the reproduction, but also plays an [sic] pivotal role in realizing the reproduction of the Broadcast Programs using a Reproduction Device by receiving broadcasts and inputting information relating to the Broadcast Programs to the Reproduction Device under its management and control. As such, it is virtually impossible for the user of said service to reproduce the Broadcast Programs unless the Service Provider conducts each of the acts in reproduction, even if the user sends a request for recording. Thus, the Service Provider can be deemed to be the actor of reproduction. ${ }^{111}$

106 Maneki TV decision of the Japanese Supreme Court, p2 (from English translation by Haruaki Murao, on file with authors).

107 Maneki TV decision of the Japanese Supreme Court, p3 (from English translation by Haruaki Murao, on file with authors).

108 Maneki TV decision of the Japanese Supreme Court, p3 (from English translation by Haruaki Murao, on file with authors).

109 Rokuraku II decision of the Japanese Supreme Court, p 2 (from English translation by Haruaki Murao, on file with authors).

110 Rokuraku II decision of the Japanese Supreme Court, p 2 (from English translation by Haruaki Murao, on file with authors).

111 Maneki TV decision of the Japanese Supreme Court, p3 (from English translation by Haruaki Murao, on file with authors). Both cases were remanded to the High Court for further consideration, where it was ultimately found that Maneki TV was directly liable for infringing the rights of public performance and of making performances transmittable, See Cite Maneki TV (2012) Intellectual Property High Court. It was also held that that the provider of the Rokuraku II technology did make 
Are these the right questions?

For the same reasons as in Singapore and Australia, the legality of copies depends entirely on "who makes" them, with no room whatsoever for consideration of factors such as the nature of the use, or whether that use might harm the copyright owner's markets. The application of the public performance right also largely turns on "who does the act?", since the determination of the actor then affects the assessment of whether the audience is "the public". The finding in Maneki that the service provider made the transmissions also meant that the transmissions were "to the public", since any subscriber could use the service. On this logic, had the individual subscriber been held to have made the transmissions, their inaccessibility to third parties would have pointed toward a finding that the transmissions were not "to the public".

$\underline{\text { EU national law approaches to making available on an individualized basis }}$

\section{France}

In May 2008 the Wizzgo company began offering a free internet-based service which allowed users to record and store programs offered by the national television stations that engage in digital broadcasting. The service involved two kinds of copies: temporary buffer copies, which Wizzgo claimed fell within the 2001 Information Society Directive's transitory copying exception, ${ }^{112}$ and permanent copies, which Wizzgo argued fell within the scope of an exception for private copying (for which remuneration would have been paid via a private copying fee levied on the recording equipment and media). ${ }^{113}$ Like the laws of Singapore, Australia and Japan, French copyright law confines the private copying exception to copies made by (and not on behalf of) the beneficiary of the copy. ${ }^{114}$ Thus, the exception would apply only if the user, not the service, was the maker of the copies.

The remote videorecorder service allowed the user to select programs from the Wizzgo program guide; selected programs would then be encrypted and stored on the Wizzgo server until the user requested them, at which point they would be sent to the user's computer and decrypted. In arguing that the user was the maker of the copies, Wizzgo stressed the automated nature of its service: the user's initial click would initiate the automatic recording of the selected program, which would be stored on the Wizzgo platform until the user took the initiative to request it. Wizzgo also contended that the buffer copies met the law's criteria for non-infringing transitory copies, which requires them to be temporary and have no independent economic value. ${ }^{115}$

the relevant copies and thus infringe the reproduction right. See Cite Rokuraku II (2012) Intellectual Property High Court.

${ }^{112}$ Directive 2001/29 on Copyright in the Information Society, art. 5(1).

113 France, Code of intellectual property, art. L. 122-5(2); L. 311-1 - L. 311-8.

114 See France, Code of intellectual property, art. L 122-5(2).

115 Id. art. L 122-5(6). 
The owners of the copyrights in the television programs countered that Wizzgo's encryption and decryption features made no difference to the nature of the service, whose purpose was to make retention, not transitory, copies on behalf of the users. The Paris Court of Appeals ${ }^{116}$ agreed that the encryption features were irrelevant (finding that the service would perform the same functions without them), and that Wizzgo created a copy for the end user to keep for as long as he or she wished. Those copies, moreover, had an economic value for the service because the service's advertising revenues depended on the number of subscribers and the number of copies made on their behalf. As a result, the service fulfilled the requirements of neither the transitory copying nor the private copying exceptions.

\section{Are these the right questions?}

The French court did not address whether the transmissions back to the end users were communications to the public; its determination that the Wizzgo service was built on illicit copies obviated any analysis of the legality of communications emanating from those copies. Accordingly, this case gives us no guidance about whether the "wrong" questions are being asked in the context of transmissions. However, we may glean some clues from the statute. French law does not define "le public", but does recognize an exception for free performances carried out in the intimacy of the "family circle". ${ }^{117}$ The family circle exception may imply that paid performances, or even free ones outside that circle, might be "public". If so, French law would offer courts more flexibility than conceptions that rely solely on the size of the audience. ${ }^{118}$ When it comes to copies however, the analysis is much more constrained, and, because of the wording of the private copying exception, once again results in liability depending almost entirely on who makes the copy.

\section{Germany}

In 2005, shift.tv began offering an internet-based personal videorecorder that enabled users to choose among free-to-air television and to request shift.tv to record specific shows for the users' subsequent viewing on demand. The RTL broadcast service initiated an action for violation of its neighboring rights to reproduce and make publicly available the broadcasts, as well as its separate right to retransmit those broadcasts. Shift.tv offered a Cartoon Network-like defense: the users made the copies, and their subsequent

\footnotetext{
${ }^{116}$ Wizzgo v. Metropole Television et autres, Paris Court of Appeals, decision of 14 December 2011, http://www.legalis.net/spip.php?page $=$ jurisprudence-decision\&id_article $=3297$

117 CPI L 122-2 ("Les copies ou reproductions réalisées à partir d'une source licite et strictement réservées à l'usage privé du copiste et non destinées à une utilisation collective"; « copies or reproductions made from a lawful source and strictly reserved to the private use of the copyist, and not intended for collective use »).

118 French domestic law, however, must be read in light of the Court of Justice of the EU's interpretation of the 2001 Information Society Directive's art. 3(1) on communication to the public; according to CJEU caselaw, "it follows from Article 3(1) of Directive 2001/29 that, by the term 'public', that provision refers to an indeterminate number of potential recipients and implies, moreover, a fairly large number of persons (SGAE, paragraphs 37 and 38, and ITV Broadcasting and Others, paragraph 32)," Case C-466/12, Svensson v Retriever Sverige, 13 Feb. 2013, para 21.
} 
transmission back to the users was not "to the public" because the transmission was communicated only to the requesting user, from her personal copy. Germany also has an exception which permits individuals to make private copies, including of audio-visual material. ${ }^{119}$ Rightholders are remunerated for some of these uses via levies. ${ }^{120}$

The German Supreme Court affirmed lower court findings that shift.tv had not infringed broadcasters' rights to reproduce or make publicly available, but did hold that it had infringed the right of retransmission.

On the reproduction right, the Court held that the user should be deemed the maker of the copies; the copies therefore would come within the German private copying exception. ${ }^{121}$ The user "initiates through the programming of the recording a purely technical process which - as found in the hearing of the evidence-occurs in a fully automated manner without external human intervention."122

With respect to the making available right, the Supreme Court held that there was no infringement because the defendant's retransmission directly to the storage lockers of individual customers meant that the service did not make the broadcasts available to "the public". ${ }^{123}$ The court's reasoning suggested that the outcome may have been different had the defendant kept copies on a server and distributed them centrally from there. ${ }^{124}$

However, the Court nonetheless found that shift.tv had violated the broadcaster's retransmission right:

42. The Defendant receives the transmission signals of the [television] broadcast with satellite antennas and transmits them simultaneously to online videorecorders, which are assigned to the sphere of the customers who are the makers of the fully automatic recordings. Since the Defendant provides its customers with "personal videorecorder" receiving devices, the Defendant's activity is within the meaning of an exploitation of a work comparable to other copyright-protected exploitations made through public replay.

43. The Defendant has made available plaintiff's [television] broadcast to a "plurality of members of the public." The Court of Appeal has correctly assumed that even a few people are a "plurality" within the meaning of $\S 15(3)$ of the German Copyright Law. ${ }^{125}$ The plaintiff"s broadcasting signal could be

119 Copyright Act of 9/9/1965 (Germany) $§ 53$.

120 For the technologies (and applicable rates) as of 2013 , see http://www.wipo.int/edocs/pubdocs/en/copyright/1037/wipo_pub_1037_2013.pdf at 65-66.

121 Shift.tv, BGH (German Supreme Court), I ZT 152/11, 11 April 2013.

122 Id. para. 11. Many thanks to David Ruther and Maximilian Vonthien, both Columbia Law School LLM Class of 2014, for translating the BGH decision.

123 Id. para. 21-22.

124 Id. para. 21.

125 Art. 15(3) provides:

The communication of a work shall be deemed public if it is intended for a plurality of members of the public. Anyone who is not connected by a personal relationship with the person exploiting 
independently and simultaneously recorded by [multiple] users of "Shift.TV" who are not connected to each other by personal relationships. The Court of Appeal rightly assumed that a plurality of members of the public received reproductions of plaintiff's broadcast. The time at which the users in fact watch the recorded broadcast is irrelevant.

In this analysis the Court focused on shift.tv's transmission of the over-the-air television signal from its antennae to its subscribers' virtual videorecorders (rather than the transmission from the recorder to the subscriber). While the users would have "made" the copies by initiating the request that the signal be downloaded into the user's remote storage box, the court deemed the relaying of the broadcast signal to the storage box for user download to be a secondary transmission. Because the target audience was members of the public in general at the moment of the offer to deliver the signals, shift.tv was engaging in a secondary transmission to the public. (By contrast, on the court's earlier analysis, once the signals had been downloaded to the personal storage space, the resulting copies were not part of the "public sphere" and therefore did not give rise to a communication to the public when they were subsequently played back to the user.) Thus all the elements of a violation of the retransmission right fell into place.

\section{Are these the right questions?}

In the context of copies, legality or infringement once again depends almost entirely on who is found to have made the copy, and not on the underlying use to which the copy is put.

With respect to the transmission of the performances, the German law operates quite differently from the others we have examined. As interpreted, it distinguishes between the service's initial retransmission to the subscribers' storage boxes (an infringement of the retransmission right) and the subscribers' separate transmissions to themselves (falling outside all of the copyright owners' exclusive rights).

The ruling that the second stage of communication was not to the public because the oneon-one transmission did not encompass a "plurality of persons" was not dispositive of liability because the entity engaging in the first stage communication was retransmitting to multiple persons. The "who makes?" question in this context thus attracts more than one answer.

Unfortunately, dividing the acts into some attributable to the service and others attributable to the end user does not eliminate the possibility for avoision. As a result, multiplying the number of potential actors and asking which one commits a copyrightinfringing act may also be a "wrong" question. Consider how the law so construed would apply to a system like Japan's Maneki TV or Rokuraku. If each subscriber provided her own receiving equipment, as occurred in those cases, there would be no transmission from the operator's receiver to "the public", and thus precisely the same end result could

the work or with the other persons to whom the work is made perceivable or made available in non-material form shall be deemed to be a member of the public. 
be achieved in a way that is copyright free. A system like Aereo's individual antennae may successfully eliminate the operator's part in the transmission as well. On this reasoning, technical architecture would continue to determine liability.

\section{EU authorities}

At the end of 2007, the Italian legislature modified the copyright law's compulsory license regime for private copying to add "remote videorecorder" services. ${ }^{126}$ The EU Commission, Internal Market and Services Directorate General, demanded that Italy rescind the measure. ${ }^{127}$ The Commission's letter condemned the Italian law as a violation of the reproduction and making available rights in the $2001 \mathrm{EU}$ Information Society Directive. The Commission rejected Italy's characterization of the service as merely enabling its customers to make private copies. The Commission also stated that no other permissible copyright exception could shelter Italy's "weakening" of the reproduction and making available rights because "the offer of video on demand services is an important part of the revenue stream of the rightholders" and remote time-shifting services "are in direct competition" with copyright owners' exclusive rights to license video on demand. "It is difficult to conceive how an exception for remote videorecording services could not in the last analysis conflict with and reduce the opportunities for commercial exploitation of licensed on demand services." ${ }^{28}$ As a result of the Commission's rebuke, ${ }^{129}$ the government never implemented the amendment, and an Italian administrative court rejected a service provider's attempt to compel implementation, observing that the characterization of the remote videorecorder service as engaging in a "making available" of content to end users was consistent with a textual analysis of the Directive. ${ }^{130}$

Another personalized transmission service fell afoul of EU norms when the Court of Justice for the European Union ruled that TV Catchup, a service that offered streaming of over the air broadcasts to U.K. users whose households possessed a television-viewing license was engaging in unlawful communications to the public. ${ }^{131}$ TV Catchup captured broadcast signals through an aerial and sent the signals to servers, which extracted individual video streams from the received signals. Upon the user's request, the streams then were sent to another server which created a separate stream for each user who requested a channel through it. An individual packet of data leaving the server was thus addressed to an individual user, not to a class of users. ${ }^{132}$ Unlike Aereo, TV Catchup did not assign each subscriber to a separate antenna, but it did divide the source transmission into separate streams corresponding to each subscriber. Pursued by British broadcasters,

\footnotetext{
126 See Decreto-Legge of Dec. 31, 2007, n. 248. Art. 5(2-ter), converted 28 February 2008 to law n. 31 of 31 December 2007. Letter n. 29900 DG Markt/D1/DB/D (2009).

128 Letter n. 29900, supra at 4-5 (translation Ginsburg).

129 The letter also warned that Italy's failure to modify the law could lead the Commission to initiate an action against Italy for non-compliance with its obligations under the EU Treaty, id. p. 5.

130 Tribunale Amministrativo Regionale, Lazio Roma, sez. II, 02.3.2012, n. 2157, pp. 41-44.

131 Case C-607/11 TVCatchup Ltd, 7 March 2013.

132 (CJEU opinion, paras 13-14).
} 
TV Catchup urged that its service was not communicating the television programming to the public, because each subscriber was receiving individualized transmissions. The CJEU rejected the defense:

31 In . . . order to be categorised as a 'communication to the public' within the meaning of Article 3(1) of Directive 2001/29, the protected works must also in fact be communicated to a 'public'.

32 In that connection, it follows from the case-law of the Court that the term 'public' in Article 3(1) of Directive 2001/29 refers to an indeterminate number of potential recipients and implies, moreover, a fairly large number of persons . . . .

33 As regards that last criterion specifically, the cumulative effect of making the works available to potential recipients should be taken into account. In that connection, it is in particular relevant to ascertain the number of persons who have access to the same work at the same time and successively .... .

34 In that context, it is irrelevant whether the potential recipients access the communicated works through a one-to-one connection. That technique does not prevent a large number of persons having access to the same work at the same time.

Are these the right questions?

Although the TV Catchup decision concerned live streaming rather than the capture-andtransmit model of Aereo, it nonetheless provides useful guidance as to the meaning of "the public" under EU law. The CJEU's holding that the "public" means "an indeterminate number of potential recipients and implies ... a fairly large number of persons" confirmed earlier judgments to the same effect. ${ }^{133}$ Unfortunately however, that definition seems vulnerable to the same kind of exploitability as the Supreme Court's in Aereo. By focusing on the number of potential recipients, rather than on the nature of the relationship between the recipient and the work, this distinction also fails to provide a principled mechanism for distinguishing between public and non-public performances.

By contrast, the EU Commission, DG Markt (as it then was) in its admonition to Italy, largely eschewed technical analyses of "who does?" and concentrated on the economic impact of the law legitimating RS-DVRs. In concluding that remote time-shifting services compete with copyright owners in the emerging market "for commercial exploitation of licensed on demand services," the Commission, we believe, was focusing on the right questions. However, if providers do not reasonably make content available for licence "on demand", ruling out such systems altogether may leave consumers with no legitimate access options. If the rationale for finding remote DVRs to infringe the communication to the public right is to prevent competition with commercial exploitation of licensed VOD services, that rationale becomes less compelling in the absence of a reasonable prospect that the copyright owner will offer those services.

133 See eg Case C-306/05 SGAE [2006] ECR I-11519, paragraphs 37-38, Case C-89/04 Mediakabel [2005] ECR I-4891, paragraph 30, and Case C-192/04 Lagardère Active Broadcast [2005] ECR I7199 , paragraph 31 . 


\section{Part 4: Lessons from Aereo and its international brethren: what might the "right" questions look like?}

The above ramble through various world jurisdictions is by no means exhaustive, but nonetheless discloses some striking patterns. In most jurisdictions, claims invoking the reproduction right succeed or fail depending almost entirely on who is found to have made the copy. If it is the user, then as long as any threshold elements are satisfied (such as being made "solely for private and domestic use" 134 ) the copy will be permitted; if it is the service provider, then every copy will be infringing. This leads to all-or-nothing outcomes: if the service is found to do the deliberate act of the subscriber, the user's rights to make private copies - including those granted by statute for targeted purposes, and paid for by levies - can disappear. If the user is found to do the act, there is no room to consider whether that particular act was an appropriate act in light of all circumstances including the service provider's contribution, and the amount paid for the use (if any).

In this context of copies, the only one of these jurisdictions to permit a more nuanced analysis of whether the use ought to be allowed is the US. There, "who did the act?" is only the first part of the analysis; there may also be a defence based on fair use. That defense requires courts take into account all statutorily enumerated factors (including the nature and purpose of the use and its effect upon the potential market for the work ${ }^{135}$ ) in order to determine whether the use is "fair" (and therefore permitted without remuneration). This framework provides some scope for considering the social benefits and economic impact of the ultimate use. However, because of the different assessment of the fairness of the use depending on whether the "doer" is found to be the service provider or the end-user, a great deal still hangs on the answer to "who makes". The Supreme Court's finding that Aereo engaged in the performances, for example, meant that the exception was so far from applying that no fair use analysis even occurred.

DG Markt's approach, if integrated into the infringement analysis, would result in airing some of the same issues as under a US fair use analysis, given the Commission's focus on whether the "timeshifted" copies would compete with licensed VOD exploitations. Moreover, the DG Markt approach seems less vulnerable to manipulation of the person who "does" the copyright infringing act, than the Supreme Court's, because it focuses squarely on the use itself.

The analysis of the right of public performance produced greater divergence between our illustrative jurisdictions. In a number of cases, the answer to "who does the act?" again dictated liability. Like the US, jurisdictions such as the EU and Singapore also focus on the size of the audience in determining whether a communication is "public". That means

\footnotetext{
134 The various threshold requirements in each state must also be satisfied, eg in Australia the copy must be for "solely for private and domestic use by watching or listening to the material broadcast at a time more convenient than the time when the broadcast is made"; Singapore requires them to be made for "private and domestic use", and in Japan "for the purpose of her personal use, family use or other similar uses within a limited circle". See discussion above.

13517 U.S.C. $\S 107$.
} 
that, if the communicator is the user, and she is transmitting only to herself, it cannot possibly be "public" - no matter how much such transmissions cumulatively interfere with licensed markets.

In Australia however, we saw an interesting approach which focused on the relationship between the copyrighted work and the recipient of the transmission, rather than the transmitter and the recipient. This focus made the question of "who performs?" much less significant, and opened room for more principled considerations of whether the ultimate use should be treated as a "public" one (and therefore within the scope of the copyright owner's exclusive rights), depending on the use's interference with the market for the work rather than on who engaged in the transmission. The Australian approach also meant that a transmission from one person to herself could, in appropriate circumstances, be "public" in nature.

Our exploratory analysis also highlighted the continuing significance of the distinction between primary and secondary infringement - as well as the circumstances in which relying on principles of secondary liability would be insufficient. As described above, Japan and Australia both take expansive approaches to the question of "who does the act". Consequently, service providers in those jurisdictions are more likely to face direct (as opposed to secondary) liability. The Australian Full Federal Court's reasoning has potential implications far beyond the context of remote DVRs. Although the Full Court acknowledged "that different relationships and differing technologies may well yield different conclusions to the 'who makes the copy' question", ${ }^{136}$ technology providers and some legal commentators alike view the uncertainty stemming from the breadth of its reasoning as seriously disincentivizing investment in cloud computing services. ${ }^{137}$ The Law Council of Australia expressed concern that, despite the Court's limiting language, "[t]he conclusion that Optus was the maker of the copies in question ... seems equally applicable to other online storage systems such as Dropbox, Sugarsync, Flickr, Google Drive, YouTube and so on."138 Cloud storage and remote backup providers could face broad direct liability under this reasoning because they design and operate wholly automated copying systems that are configured to make copies in response to requests

136 National Rugby League Investments v Singtel Optus [2012] FCAFC 59, at [100].

137 See e.g. Rebecca Giblin, Stranded in the Technological Dark Ages: Implications of the Full Federal Court's Decision in NRL v Optus 35 European Intellectual Property Review 632 (2012). Responding to a recent inquiry into Australia's copyright exceptions, eBay described the Optus decision as"creat[ing] serious disincentives for the development of cloud services in Australia" (http://www.alrc.gov.au/sites/default/files/subs/93._org_ebay.pdf, at 9); the Internet Industry Association described the standard as unacceptably uncertain and as 'creat[ing] a barrier to the adoption of cloud technology.'

(http://www.alrc.gov.au/sites/default/files/subs/253._org_internetindustryassociation.pdf at 5-6); Google finds that it 'rendered the status of a wide range of ... applications and services highly uncertain', and 'impose[d] barriers to the introduction of remote storage services including cloud computing and network PVRs'. (http://www.alrc.gov.au/sites/default/files/subs/217._org_google.pdf at $\mathrm{p} 35$.

138 http://www.alrc.gov.au/sites/default/files/subs/263._org_lawcouncilaustralia.pdf at 7 . 
from third parties. This is precisely the kind of activity the Full Federal Court in Optus held should result in direct liability, albeit, it bears emphasis, in circumstances where the service provider was itself proposing the content.

The most useful and intuitive of these systems make copies without any specific direction from the user, potentially making such providers more intimately involved with their users' copies than was Optus. Consider Dropbox, for example. The actual user has only to install the application, login, and start putting material in her Dropbox folder. Then she can sit back while the Dropbox service handles everything else: actively monitoring that folder, automatically copying and synchronizing new and changed files to each device over the internet, and encrypting those files when they reach Dropbox's servers. ${ }^{139}$ Who makes those copies? While the Dropbox scenario concerns content the user herself posted, rather than content initially supplied by the storage service (as was the case in Optus), Australian-based service providers have expressed concern that Optus' characterization of "who makes" might mean that they could deemed the "makers." Accordingly, they highlight this risk as a key barrier to investment in cloud technologies. ${ }^{140}$ (The asserted risk both uproots Optus from its facts, and may overstate the extent to which Optus in fact affects decisions about cloud-based investments; other considerations, such as the absence of flexible exceptions that would permit user copying in some circumstances, and the lack of any Australian safe harbour protecting Dropboxstyle providers may also play a role in the current paucity of such services in Australia.) In Japan, technology providers have also argued that the broad interpretation of "maker" is a serious barrier to investment in (and adoption of) cloud-based technologies. ${ }^{141}$ Setting aside the possibility that some of these statements may be self-serving, it is clear that a too-ready finding that the service provider itself engaged in the act can undesirably blur the line between primary and secondary infringement.

On the other hand, however, it is problematic to rely on secondary infringement principles to obtain redress in situations where the law that governs primary infringement is unsatisfactory. For example, a copying exception that applies to all uses, regardless of their nature and impact, will extend to some that ought not to be permitted. Similarly, a conception of "the public" that relies on transmissions being directed to a "large" number of people will fail to fully capture all of the circumstances in which a transmission might be public in nature. Where principled mechanisms for making determinations about primary infringement are missing, principles of secondary liability cannot fill the gap.

\footnotetext{
$139 \mathrm{https}: / / \mathrm{www} . \mathrm{dropbox} . \mathrm{com} / \mathrm{help} / 4 / \mathrm{en}$.

$140 \quad$ Supra, note 139.

${ }^{141}$ See, e.g., A World Without Cablevision nor Sony: How Japanese Courts Find Providers of Personal Locker and Content-Sharing Services Liable, https://papers.ssrn.com/sol3/papers.cfm?abstract_id=2238359, from section entitled 'Effect of legal Environment on Cloud Businesses in Japan and the U.S.' (pp28-33).
} 


\section{Part 4. What are the "right" questions?}

If we are correct that copyright law in many cases asks the "wrong questions", what then are the right ones?

Given the significant (and increasing) potential for arbitrary outcomes to the "who does?" analysis, we consider that a better approach would centre inquiry on whether, after full reflection on the contributions of each party, the use should be permitted - instead of allowing ancillary considerations to determine liability.

In the context of the reproduction right, the US law is very close to having such a framework already. In practice however, at least in the context of the kinds of technology this paper addresses, there are two barriers. First, as discussed above, fair use considerations can apply very differently depending on who is found to "make" the copy. Second, the application of those principles has been problematic. In 1984, the US Supreme Court held that it was a "fair use" for consumers to use Sony's Betamax VCR to timeshift free broadcast television programming. Subsequently, many commentators and some courts have treated Sony as imprimatur for any timeshifting whatsoever. ${ }^{142}$ However, Sony was far from a blanket authorization of any and all consumer timedeferred copying of television broadcasts. While the Sony court assumed that consumers should be entitled to watch at their convenience programming that they had been invited to view for free, ${ }^{143}$ the court reached the conclusion that the copies made there were not infringing only after deliberating considerations relating to market harm, cost and difficulty of copying, and the nonexistence of copyright owner-supplied alternatives to inconvenient broadcast times. ${ }^{144}$

Technologies such as Aereo are readily distinguishable from the Betamax. Most importantly, they have much more potential to compete with remunerated markets for making the same content conveniently available on demand (which have developed significantly since the $1980 \mathrm{~s}$, now offering multiple alternative viewing opportunities to the original broadcast time). Moreover, the technologies themselves have eliminated a great deal of "friction" from the copying process (notably, as in the case of DISH's "autohop" service, by automatically deleting the advertisements). However, there still seems to be a widely held view that "time shifting" = "fair use" regardless of such distinctions. ${ }^{145}$ This cannot be correct. Such shortcuts remove the nuance from the fair

142 See eg Fox Broadcasting Co. Inc. v. Dish Network, L.C.C., 905 F.Supp.2d 1088 (affirmed by Fox Broad. Co., Inc. v. Dish Network L.L.C. 723 F.3d 1067 (9th Cir. 2013) (also note opinion amended and en banc rejection by Fox Broadcasting Co., Inc. v. Dish Network L.L.C., --- F.3d ----, 2014 WL 260572, 14 Cal. Daily Op. Serv. 765 (9th Cir.(Cal.) Jan 24, 2014) (NO. 12-57048)).

143464 U.S. at 421, 423-25 and n. 8.

144 See Rebecca Giblin \& Jane C. Ginsburg, We Need to Talk About Aereo: Copyright-Avoiding Business Models, Cloud Storage and a Principled Reading of the "Transmit" Clause, Colum. L. \& Economics Working Paper No. 480 (2014), 35.

145 See eg Fox Broadcasting Co. Inc. v. Dish Network, L.C.C., 905 F.Supp.2d 1088 (affirmed by Fox Broad . Co., Inc. v. Dish Network L.L.C. 723 F.3d 1067 (9th Cir. 2013) (also note opinion amended 
use framework, and render the analysis as binary as those in other jurisdictions we canvassed above. Asking "are the copies made for purposes of time-shifting?" is a "wrong" question, at least where an answer of "yes" equates those purposes with "noninfringing". The use-based focus we advocate is achievable within the existing framework if, instead of taking such mental shortcuts, all fair use analyses were conducted with due consideration of all relevant circumstances, including awareness of how technologies and markets have changed since Sony, and the contributions made by provider and user.

In the context of the public performance right, the US framework may be missing some analytic steps before it can focus on the desirability of the ultimate use. Nonetheless, the Supreme Court in Aereo did open the door to future judicial consideration of the "right" questions by stating that whether or not recipients constitute "the public" often depends on their relationship to the underlying work. ${ }^{146}$ The court's adverting to a "possessory" relationship between the user and the work explicitly recognizes that the use of the work is significant in determining whether there is any infringing public performance at all. As we have argued elsewhere, such considerations could be integrated into the US law's public performance analysis by focusing more on the transmission's economic impact on the copyright owner (whether via an Australian-style interpretation of "the public" or otherwise). ${ }^{147}$

\section{Conclusions}

We have argued that asking the "wrong" questions leaves the law vulnerable to avoision. As the law now stands - in the US as well as in a number of other jurisdictions - the focus on the "wrong" questions is sending copyright business models in the direction of tax planning, wastefully devoting resources to hyper-technical compliance with the letter rather than the meaning and purpose of the law. ${ }^{148}$

Liability should not turn on ancillary questions such as who did the act, whether unique copies were made, or the size of a transmission's potential audience, because these bases for (or against) liability can be vulnerable to manipulation and exploitation. Instead, the focus should train on the use itself. Does the use duplicate or displace existing forms of exploitation, supplanting markets, or creating new ones? Aereo looks a lot like a cable retransmitter of broadcast signals - a use clearly encompassed within the scope of copyright's exclusive rights. But Aereo is also providing users with an antenna (and a lot

of computing resources) through which consumers may access broadcast $\mathrm{TV}$, something

and en banc rejection by Fox Broadcasting Co., Inc. v. Dish Network L.L.C., --- F.3d ----, 2014 WL

260572, 14 Cal. Daily Op. Serv. 765 (9th Cir.(Cal.) Jan 24, 2014) (NO. 12-57048)).

146 Am. Broad. Cos., Inc. v. Aereo, Inc., 134 S. Ct. 2498, at 2510 (2014).

147 Rebecca Giblin \& Jane C. Ginsburg, We (Still) Need to Talk About Aereo: New Controversies and Unresolved Questions After the Supreme Court's Decision (forthcoming, 38 Columbia Journal of Law $\&$ the Arts (2015)).

148 See Susy Frankel, "The International Copyright Problem and Durable Solutions," 15 Vanderbilt J. Ent. And Tech. L. (forthcoming 2015). 
which they would be perfectly entitled to do with their own equipment from their own rooftops. But recourse to established forms of exploitation within the scope of exclusive rights (cable), or to established non-infringing activities (rooftop antenna) may reduce to a battle of analogies. The search for the "killer metaphor" obscures consideration of the "right" questions, such as whether, why and how remote antennae are different from rooftop ones. Asking the "right" questions should lead to principled conclusions about the legal effects (if any) that should flow from distinctions between technological modes of exploitation. 